\title{
Identification and Evaluation of the Antimicrobial Potential of Strains Derived from Traditional Fermented Dairy Products of Iran as A Biological Preservative Against Listeria monocytogenes, Staphylococcus aureus, Salmonella enterica and Escherichia coli
}

\section{Ahmad Nasrollahzadeh ${ }^{1}$, Morteza Khomeiri*1, Mandana Mahmoudii ${ }^{1}$, Alireza Sadeghi ${ }^{1}$, Maryam Ebrahimi ${ }^{1}$}

Department of Food Microbiology, Faculty of Food Sciences and Industries, Gorgan University of Agricultural Sciences and Natural Resources, Gorgan, Iran

\subsection{9/ijmm.13.5.391}

\section{ABSTRACT}

Background: Today, despite improved food safety, nearly a quarter of the population is at risk for foodborne diseases. Therefore, the use of lactic acid bacteria and their metabolites due to their potential health benefits, safety and production of natural antimicrobial compounds is an appropriate solution to reduce microbial spoilage of food.

Materials \& Methods: In this research, lactic isolates were identified by PCR method and Micro-dilution method was used to evaluate the antimicrobial activity of the Cell-Free spent Medium (CFSM).

Results: The sequencing of PCR products showed that the species identified were Lactobacillus and Enterococcus species. Evaluation of the antibacterial properties of the CFSM on the growth of Gram-positive bacteria showed that all isolates were able to prevent the growth of these pathogens, and their inhibitory percentages varied from 86.81 to 38.81 percent. The results of inhibitory effects of lactic isolates on the growth of two gram-negative bacteria of Escherichia coli and Salmonella enterica also showed that the inhibitory levels of the isolates were varied from 2.43 to 36.43 percent and 14.1 to 31.97 percent, respectively. A comparison of the inhibitory effect of lactic isolates on pathogenic bacteria showed that the inhibitory effect of all lactic isolates on gram-positive bacteria was significantly $(P<0.05)$ more than their effect on gramnegative bacteria.

Conclusion: The results of this study showed that native dairy lactic acid isolates and their metabolites could be used as biological preservatives or in combination with synthetic preservatives in the food and drug industry.

Keywords: Antimicrobial, Lactic acid bacteria, Listeria monocytogenes, Staphylococcus aureus, Natural preservatives

Received: 2019/08/18; Accepted: 2019/11/30; Published Online: 2020/01/10

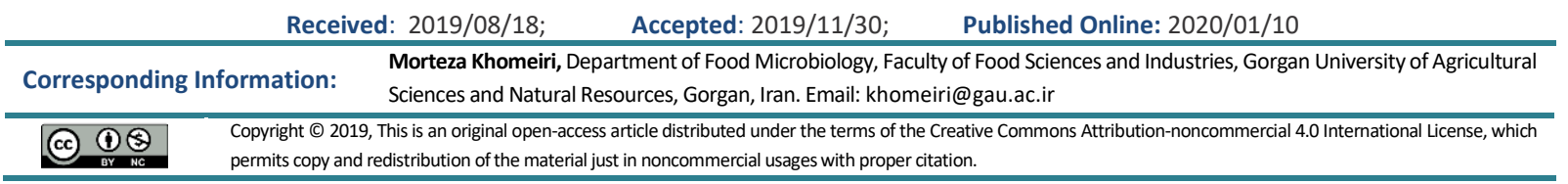

Use Mobile to scan and read the article online

Nasrollahzadeh A, Khomeiri M, Mahmoudi M, Sadeghi A, Ebrahimi M. Identification and Evaluation of the Antimicrobial Potential of Strains Derived from Traditional Fermented Dairy Products of Iran as A Biological Preservative Against Listeria monocytogenes, Staphylococcus aureus, Salmonella enterica and Escherichia coli. Iran J Med Microbiol. 2019; 13 (5) :392-405

Download citation: BibTeX | RIS | EndNote | Medlars | ProCite | Reference Manager | RefWorks
Send citation to:
8 Mendeley
2 zotero
RefWorks

\section{Introduction}

The term "foodborne diseases" is more commonly referred to as food poisoning, is used to describe the gastrointestinal side effects that occur following the consumption of certain foods or drinks. Foodborne illnesses affect 48 million people in the United States each year (1-3). There are more than 200 identified diseases that can be transmitted through food and by various factors such as bacteria, fungi, viruses, and parasites. According to food safety and health experts, millions of people around the world each year are affected by foodborne pathogens. While food supply and production in the United States is one of the safest in the world, the US Centers for Disease Control and Prevention estimate that foodborne illnesses cause 76 million 
illnesses, more than 300,000 per year hospitalization, and 5,000 deaths in the United States (4-6). This figure is also estimated to be 2366,000 in England and Wales, 21138 hospitalizations, 718 deaths (7). On the other hand, with the frequent spread of diseases caused by new pathogens, the use of antibiotics in livestock breeding and resistance gene transfer to human, and current concerns about bovine spongiform encephalitis are just a few examples of these risks (8).

Thus, despite extensive advances in health and food safety food borne pathogens still cause many poisoning and digestive problems for consumers. Listeria monocytogenes, Staphylococcus aureus, Salmonella enterica and Escherichia coli are food borne pathogens that cause problems for consumers for various reasons such as lack of hygiene before, during or after food production.

Over the past decade, there has been a growing interest in improving the quality and enhancement of food safety by replacing conventional conservation and maintenance systems with natural alternatives. Biopreservatives are defined as "the use of microorganisms or their metabolites to prevent spoilage, enhance food safety and shelf life" $(9,10)$. Lactic Acid Bacteria (LAB) are bio-preservatives that play a key role in the fermentation process (11). In addition, it has been shown that LAB have antimicrobial activity in fermented foods and therefore can be used as natural preservatives to inhibit the growth of food born pathogenic bacteria and fungi $(12,13)$. Lactic acid bacteria produce a variety of metabolites including organic acids, bacteriocins, hydrogen peroxide and low molecular weight metabolites such as diacetyl and reuterin with inhibitory effects on Gram-negative and Gram-positive producing food spoilage bacteria (such as Micrococcus, Pseudomonas, Moraxella, Acinetobacter, Shewanella) and as well as food poisoning bacteria (such as S. aureus, L. monocytogenes, Clostridium botulinum type E, Yersinia enterocolitica) (14). The mechanism of action of bacteriocins is to destabilize the cells and increase the permeability of the cytoplasmic membrane. Lactic bacteria produce a wide range of bacteriocins (nisin, pediocin, lactacin, divergine, diplocin, elactosterone) that have a different antimicrobial spectrum but are more likely to be effective on Gram-positive pathogenic and food spoilage bacteria (15). In this study, we tried to evaluate the antimicrobial potential of a number of lactic acid bacteria isolated from traditional products against some food-borne pathogens.

\section{Materials and Methods}

\section{Bacterial Strains}

In this study, bacteria isolated from local yogurt and milk and camel dooq (yogurt drink) of Golestan province with codes M109, M8, Y92, Y91, 8C, Y102, M153, Y73, Y52, Y98, Y89 that were prepared from microbial collection in Department of Food Science and Technology of Gorgan University, were used. To investigate the antimicrobial properties of the pathogenic bacteria, L. monocytogenes (ATCC 19115, PTCC 1298), S. enterica (ATCC 14028, PTCC 1709), E. coli (ATCC 25922, PTCC 1399) and S. aureus (ATCC 25923, PTCC 1431) were used. All pathogenic bacteria were purchased from the Persian Type Culture Collection (PTCC), Tehran, Iran.

\section{Activation of Isolates and Phenotypic Identification}

For this purpose, the isolates were first cultured in MRS broth under anaerobic conditions at $37^{\circ} \mathrm{C}$. Identification of the isolates in early stages was performed using phenotypic criteria such as colony shape and cell morphology, Gram staining and catalase activity. MRS agar and MRS broth and yeast extracts were prepared from Merck, Germany and Muller Hinton Agar (MHA) from Sigma, USA.

\section{Molecular Identification of Isolates}

The DNA extraction was carried out using a commercial DNA extraction kit (Takapouzist, South Korea). To identify molecularly LAB by PCR, Universal primers (1492R: 5 '-GGTTACCTTGTTACGACTT-3' and 27F: 5'-AGAGTTTGATCCTGGCTCAG-3') were used to amplify $16 \mathrm{~S}$ rDNA variable regions. The length of the amplified DNA fragment was $1500 \mathrm{bp}$.

The PCR was performed in a volume of $30 \mu \mathrm{L}$ with optimized amounts of $15 \mu \mathrm{L}$ of Red 2X Master Mix (Macrogen, South Korea), $5.5 \mu \mathrm{L}$ of each primer, $3 \mu \mathrm{L}$ of DNA and $11 \mu \mathrm{L}$ of water in a thermo cycler (Corbett research, CG1-96, Australia).

PCR products were sent to Macrogen Company in South Korea for sequencing. Sequences were compared with available sequences in the world gene bank (NCBI) using the Blast program. Isolates with the highest percentage of similarity of their sequences with the stored sequences in the gene bank were identified as the same species.

\section{Evaluation of Antibacterial Activity of the Isolates}

The micro-dilution method was used to evaluate the antimicrobial activity of the Cell Free Spent Medium (CFSM) of 24-hour culture of lactic isolates against pathogenic bacteria including $L$. monocytogenes, $S$. aureus, $S$. enterica and $E$. coli. At first, LAB were cultured in MRS broth under anaerobic conditions at $37^{\circ} \mathrm{C}$. At the end of the logarithmic phase, CFSMs were centrifuged at $6,000 \mathrm{rpm}$ for $10 \mathrm{~min}$ and then filtered with a $0.45 \mu \mathrm{m}$ syringe filter and were used for antimicrobial testing. To determine the antimicrobial effect, $185 \mu \mathrm{L}$ of CFSM of each lactic isolate along with $15 \mu \mathrm{L}$ of pathogenic bacteria $\left(10^{5} \mathrm{cfu} / \mathrm{mL}\right)$ were added into each well. After $24 \mathrm{~h}$ of incubation under aerobic conditions at $37^{\circ} \mathrm{C}$, the samples 
absorbance were measured at $600 \mathrm{~nm}$. The inhibitory percentage of lactic isolates was calculated as follows:

1- [the growth in test well/ the growth in positive control well] $\times 100$

\section{Statistical Analysis}

The results of this study were analyzed by one-way ANOVA and LSD at the significant level of 0.05 in three replications using SPSS 19 (SPSS In., Chicago, IL., USA) and Microsoft Excel 2007 software was used to draw charts.

\section{Results}

\section{Molecular Identification of Activated Isolates}

To confirm DNA replication, the PCR products were loaded onto gel electrophoresis (Figure 1).

As shown in Figure 1, the PCR products of each of the 11 extracted DNA samples had a length of $1500 \mathrm{bp}$. After blasting the PCR product sequences with the data in the $\mathrm{NCBI}$ database, it was found that the isolates were Lactobacillus acidophilus, Lactobacillus fermentum, Enterococcus faecium, Lactobacillus brevis and Lactobacillus rhamnosus (Table 1). Based on the above results and the obvious differences between molecular and biochemical identification, it can be concluded that molecular identification of microbial strains using the $16 \mathrm{~S}$ rDNA gene region is the most accurate method.

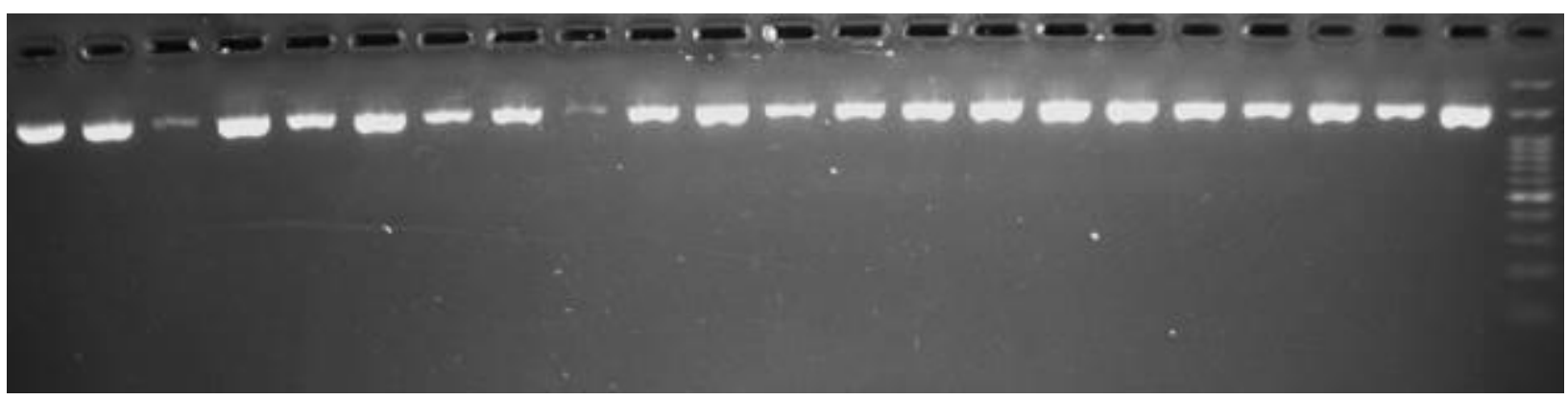

Figure 1. Gel Electrophoresis of PCR products containing specific primer with 500 Bp target sequence on 1.5\% gel agarose. 1: Marker, 2: Positive control (Lactobacillus plantarum), No. 12 to 22: activated samples from 1 to 11 , respectively.

Table 1. Sequencing results of activated isolates and comparison of results obtained from biochemical and molecular identification

\begin{tabular}{|c|c|c|c|c|}
\hline No. & Isolate code & source & Molecular identification & Biochemical identification \\
\hline 1 & Y92 & Local yogurt & Lactobacillus brevis & Lactobacillus spp. \\
\hline 2 & M153 & Local milk & Lactobacillus rhamnosus & Lactobacillus spp. \\
\hline 3 & $\mathrm{C} 8$ & Camel dooq & Enterococcus faecium & Pediococcus pentosaceus \\
\hline 4 & M109 & Local milk & Enterococcus faecium & Enterococcus spp. \\
\hline 5 & Y98 & Local yogurt & Lactobacillus acidophilus & Lactobacillus spp. \\
\hline 6 & Y52 & Local yogurt & Lactobacillus brevis & Lactobacillus spp. \\
\hline 7 & M8 & Local milk & Enterococcus faecium & Enterococcus spp. \\
\hline 8 & Y91 & Local yogurt & Lactobacillus reuteri & Lactobacillus spp. \\
\hline 9 & Y102 & Local yogurt & Lctobacillus rhamnosus & Lactobacillus spp. \\
\hline 10 & Y73 & Local yogurt & Enterococcus faecium & Enterococcus hirae \\
\hline 11 & Y89 & Local yogurt & Lactobacillus rhamnosus & Lactobacillus spp. \\
\hline
\end{tabular}




\section{Antibacterial Activity of the Isolates}

Among the identified isolates, 11 isolates of different genera and species were selected and then their antimicrobial activity against pathogenic bacteria was investigated by micro-dilution method (Figures 2 to 5). The results of the evaluation of the inhibitory effects of the CFSM of lactic isolates on the growth of L. monocytogenes (Figure 2) showed that the percentage of inhibition of the CFSM of the lactic isolates were varied from 29.96 to 30.99 percent. Among the isolates, E. faecium C8 isolated from camel dooq showed the highest inhibitory percentage $(P<0.05)$. Also, no significant difference was observed in the inhibitory percentage among L. rhamnosus Y89, E. faecium M109 and L. reuteri Y91. Also, L. brevis Y92 had the lowest inhibitory percentage $(P<0.05)$.

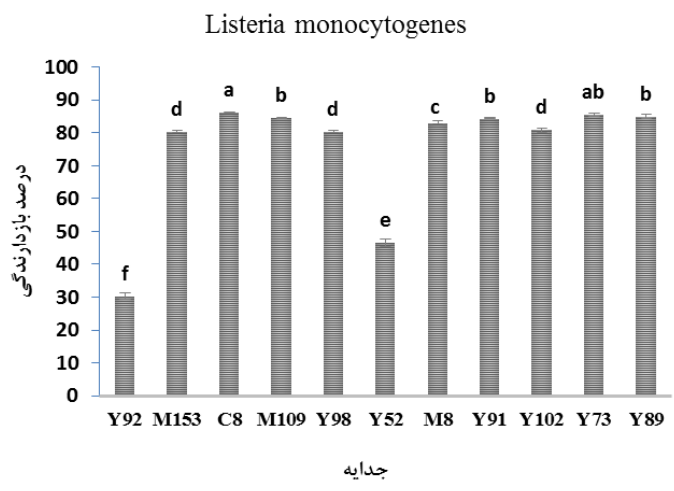

Figure 2. Inhibitory effects of CFSM of lactic isolates on growth of Listeria monocytogenes

* Similar letters in each column indicate no significant difference at 0.05 level.

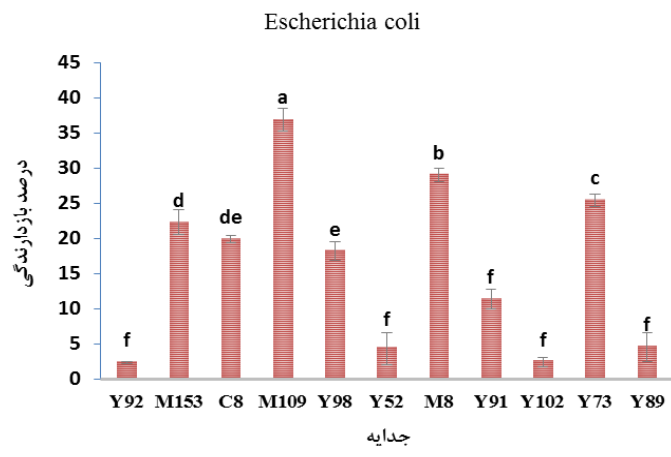

Figure 4. The inhibitory effects of the CFSM of lactic isolates on the growth of Escherichia coli

* Similar letters in each column indicate no significant difference at 0.05 level.
The results of the evaluation of the inhibitory effects of CFSM of lactic isolates on the growth of $S$. aureus are shown in Figure 3. As shown, L. rhamnosus Y89 and E. faecium M109 had the highest percentage of inhibition against $S$. aureus. Also E. faecium $\mathrm{Y} 73$ had significantly the least inhibitory effect $(P<0.05)$.

In another part of this study, the inhibitory effects of the CFSM of lactic isolates on the growth of two gram-negative bacteria including $E$. coli (Figure 4) and S. enterica were investigated (Figure 5). The results showed that the inhibitory rate of the isolates on the growth of $E$. coli and S. enterica varied from 2.42 to 36.93 percent and from 1.14 to 31.97 percent, respectively. Also, the highest inhibitory effect on $E$. coli belonged to $E$. faecium M109 isolated from milk and the lowest inhibitory rate belonged to L. brevis Y92 isolated from yogurt $(P<0.05)$.

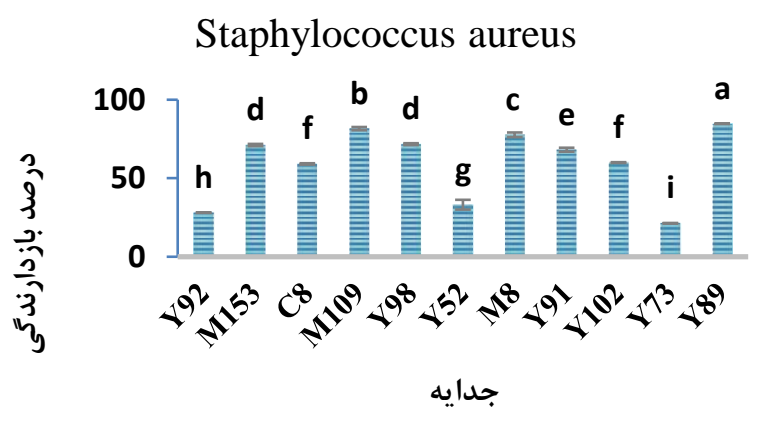

Figure 3. The inhibitory effects of the CFSM of lactic isolates on the growth of Staphylococcus aureus

* Similar letters in each column indicate no significant difference at 0.05 level.

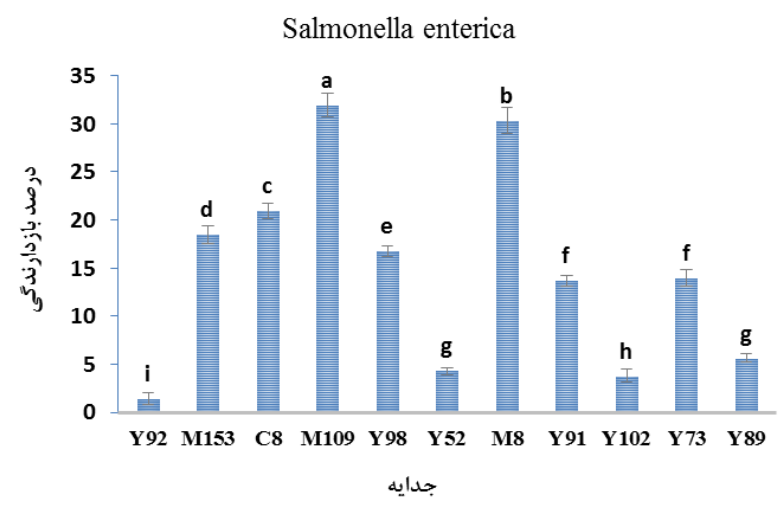

Figure 5. The inhibitory effects of the CFSM of lactic isolates on the growth of Salmonella enterica

* Similar letters in each column indicate no significant difference at 0.05 level.

* Y: Local yogurt; M: Local milk; C: Camel dooq 
Table 2. Comparison of inhibitory effect of lactic isolates on pathogenic bacteria

\begin{tabular}{|c|c|c|c|c|c|}
\hline No. & Isolate code & $\begin{array}{c}\text { Listeria } \\
\text { monocytogenes }\end{array}$ & $\begin{array}{c}\text { Staphylococcus } \\
\text { aureus }\end{array}$ & Escherichia coli & $\begin{array}{c}\text { Salmonella } \\
\text { enterica }\end{array}$ \\
\hline 1 & Y92 & $0.92^{a} \pm 30.29$ & $0.17^{\mathrm{a}} \pm 28.12$ & $0.15^{b} \pm 2.44$ & $0.64^{b} \pm 1.4$ \\
\hline 2 & M153 & $0.42^{a} \pm 80.46$ & $0.69^{b} \pm 71.17$ & $1.76^{\mathrm{c}} \pm 22.29$ & $0.9^{d} \pm 18.46$ \\
\hline 3 & $\mathrm{C} 8$ & $0.085^{\mathrm{a}} \pm 86.14$ & $0.43^{b} \pm 59.11$ & $0.53^{c} \pm 19.96$ & $0.74^{c} \pm 20.93$ \\
\hline 4 & M109 & $0.08^{a} \pm 84.48$ & $1.04^{b} \pm 81.59$ & $1.61^{c} \pm 36.93$ & $1.21^{d} \pm 31.97$ \\
\hline 5 & Y98 & $0.42^{a} \pm 80.46$ & $0.6^{b} \pm 71.71$ & $1.36^{c} \pm 18.21$ & $0.55^{c} \pm 16.74$ \\
\hline 6 & Y52 & $1.25^{\mathrm{a}} \pm 46.56$ & $3.12^{b} \pm 33.15$ & $2.29^{c} \pm 4.41$ & $0.37^{c} \pm 4.31$ \\
\hline 7 & M8 & $0.5^{\mathrm{a}} \pm 83.06$ & $1.48^{b} \pm 77.67$ & $0.95^{c} \pm 29.08$ & $1.32^{c} \pm 30.34$ \\
\hline 8 & Y91 & $0.17^{\mathrm{a}} \pm 84.4$ & $1.3^{b} \pm 68.14$ & $1.4^{\mathrm{C}} \pm 11.44$ & $0.52^{c} \pm 13.67$ \\
\hline 9 & Y102 & $0.67^{a} \pm 80.87$ & $0.26^{b} \pm 59.98$ & $0.67^{c} \pm 2.5$ & $0.68^{c} \pm 3.78$ \\
\hline 10 & Y73 & $0.59^{a} \pm 85.49$ & $0.13^{c} \pm 21.38$ & $0.88^{b} \pm 25.43$ & $0.83^{d} \pm 13.95$ \\
\hline 11 & Y89 & $0.67^{\mathrm{a}} \pm 84.9$ & $0.17^{\mathrm{a}} \pm 84.71$ & $2.07^{b} \pm 4.63$ & $0.46^{b} \pm 5.65$ \\
\hline
\end{tabular}

Similar letters in each row indicate no significant difference at the 0.05 level.

\section{Discussion}

According to the results of this study, Lactobacillus and Enterococcus genera were isolated and identified as lactic isolates from traditional fermented dairy products. Other studies have also confirmed the presence of these genera in traditional and native dairy products. In this regard, research by Haghshenas et al. (2014) indicated that they were able to identify Enterococcus mundtii 50H, Enterococcus daurans 39C and Enterococcus faecalis $13 \mathrm{C}$ in traditional dairy products (18). Tulumoğlu et al. (2014) also identified 7 strains of Lactobacillus fermentum in a study of more than 100 isolates from Tulum cheese (19). Research by Leite et al. (2015) on the study of lactic acid bacteria from Brazilian kefir grains led to the identification of Leuconostoc mesenteroides, Lactococcus lactis, Lactobacillus paracasei isolate and Lactococcus lactis subsp. lactis (16). Thus, the Lactobacillus and Enterococcus genera are the most lactic acid bacteria isolated from traditional and native dairy products. The results of evaluation of the inhibitory effect of lactic isolates on L. monocytogenes and Staphylococcus aureus showed that all isolates had good antibacterial activity against these two pathogens and the highest inhibition percentage was related to $\mathrm{C} 8$ isolate (isolated from camel dough) and Y89 (isolated from local yogurt), respectively. These results are consistent with the findings of Leite et al. (2015) who showed that the lactic isolates of Lactococcus lactis, Leuconostoc mesenteroides and Lactobacillus paracasei have inhibitory effect on L. monocytogenes, S. aureus, S. enterica and $E$. coli (16). The inhibitory properties of lactic isolates can be attributed to various antimicrobial metabolites such as lactic acid, acetic acid, hydrogen peroxide, carbon dioxide and bacteriocin $(20,21)$. Casaburi et al. (2016) also isolated Lactobacillus curvatus 54M16 from Campania's traditional fermented sausage. It produced more than one bacteriocin, including saccharin $\mathrm{X}, \mathrm{T}$ and $\mathrm{P}$, and showed inhibitory effects on L. monocytogenes, Bacillus cereus, and Brochothrix thermosphacta (22). The results of the inhibitory effects of lactic isolates on the growth of $E$. coli and $S$. enterica also showed that all strains identified from traditional Iranian dairy products except a few strains were able to inhibit the growth of mentioned pathogenic bacteria and the highest inhibition percentage was related to M109 isolate (isolated from local yogurt). In addition, it was found that, among all the isolates, the highest inhibition percentage was related to $\mathrm{C} 8$ isolated from camel dough. Also, the cause of less resistance of Grampositive bacteria than Gram-negative bacteria can be attributed to the impermeable wall and the complex and multilayer structure of these bacteria as well as the presence of an outer membrane. Sabir et al. (2010) also isolated $L$. acidophilus strain Z1L from kefir, which was able to significantly inhibit $E$. coli growth (23). Paris Silia et al. (2015) also evaluated the antimicrobial effect of different species of Lactobacillus genus from traditional Cucido Mexican cheese. Their results showed that the bacteriocin-like compounds produced by these bacteria exhibit significant antimicrobial activity against Listeria innocua, Staphylococcus aureus, Salmonella typhimurium, and Escherichia coli. Recently, numerous reports have been published on the antimicrobial activity of lactic acid isolates (24-26). For example, Angmo et al. (2016) isolated and identified Lactobacillus plantarum KJ722784 from Ladakh and Assohoun et al. (2016) isolated and identified Lactobacillus fermentum from Doklu that both isolates were able to produce antimicrobial compounds including bacteriocins $(24,25)$.

Bacteriocins inhibit cell wall synthesis by binding to lipid II, leading to cell death by removing lipid II from the membrane structure and pore formation. They also inhibit DNA replication by blocking the activity of DNA gyrase enzyme, destroying DNA by nuclease 
activity, and blocking protein synthesis by disrupting ribosomal activity (27). According to the results of Schillinger et al. (2005), L. acidophilus had significant accumulation potential against pathogenic bacteria due to its high level of hydrophobicity on the cell surface. There is a direct relationship between the rate of cell wall hydrophobicity and the ability of lactic acid bacteria to accumulate against pathogenic bacteria (28). L. acidophilus and Lactobacillus gasseri isolated by Fernandez et al. (2003) were also able to prevent the growth of Salmonella, Listeria and Campylobacter bacteria without interfering with the microbial flora of the gastrointestinal tract (29). Lactic acid bacteria also have the ability to decrease cholesterol levels, immune system immunization and anti-tumor activity (30).

Due to the importance of specific properties of lactic isolates from traditional and indigenous dairy products, identifying and evaluating the potential properties of these isolates is of great importance.

According to the results of this study, lactic strains isolated from traditional dairy products can be used separately or in combination with other preservatives to reduce the consumption of synthetic preservatives or as starter culture in the food industry.

\section{Conclusion}

The sequencing results of PCR products led to the identification of Lactobacillus and Enterococcus genera from traditional fermented dairy products. Also the results of evaluation of the inhibitory effect of Lactic isolates on the growth of L. monocytogenes and $S$. aureus showed that all isolates were able to prevent the growth of these two pathogens and their inhibitory percentages varied from 86.14 to 14.14 percent. L. rhamnosus $Y 89$ isolated from yogurt and $E$. faecium isolated from camel dough showed the highest inhibition percentage on L. monocytogenes and S. aureus, respectively.

Comparison of the inhibitory effect of lactic isolates on pathogenic bacteria showed that the inhibitory effect of all tested lactic isolates on Gram-positive bacteria was significantly $(P<0.05)$ more than their effect on Gram negative bacteria. According to the results of this study, all strains isolated and identified from these dairy products are able to prevent the growth of Gram-positive pathogenic $L$. monocytogenes and $S$. aureus and except for some strains, all lactic isolates have the ability to inhibit the growth of Gram-negative bacteria $E$. coli and $S$. enterica. Therefore, it is suggested that the lactic isolates obtained from yogurt, milk and camel dough be used as bio-preservatives in the food and drug industry.

\section{Acknowledgment}

\section{Conflict of Interest}

Authors declared no conflict of interests. 


\title{
شناسايى و بررسى قابليت ضد ميكروبى سويههاى حاصل از لبنيات تخميرى سنتى ايران بهعنوان
}

\section{نكهدارنده بيولوزيكى بر باكترىهاى بيمارىزا ليستريا مونوسيتوزنز، استافيلوكوكوس اورئوس، سالهونلا انتريكا و اشريشيا كلاى}

\author{
مر تضى خميرى"'، احمد نصر اللهزاده'، عليرضا صادقى'، ماندانا محمودى'، مريم ابراهيمى'
}

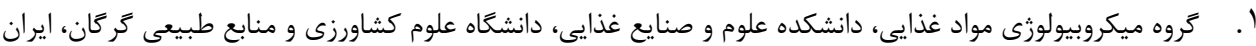

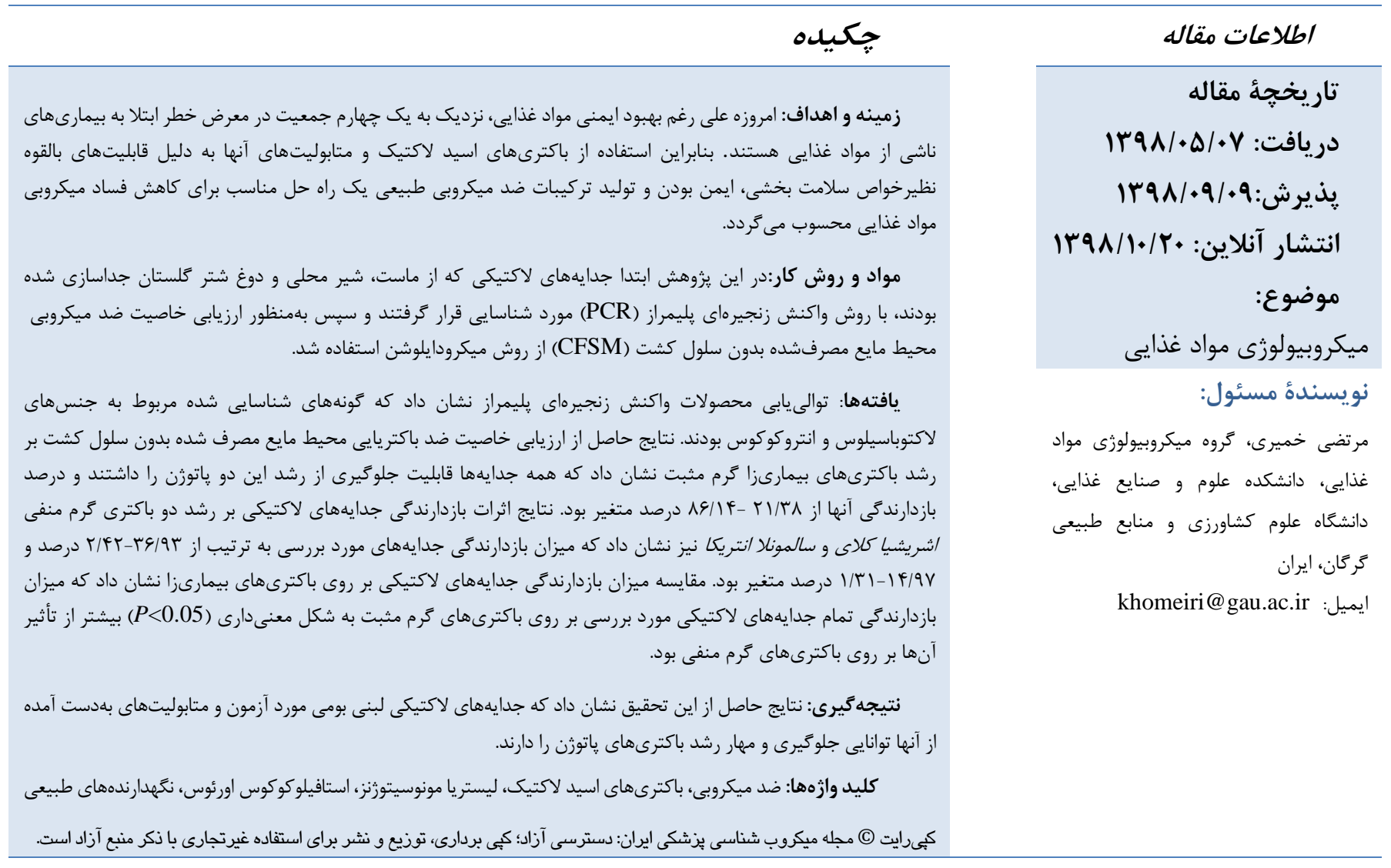

مقدمه

منتقل شوند. بر اساس نظر كارشناسان بهداشت و ايمنى مواد غذايى، هر ساله ميليونها نفر در سراسر جهان به عوامل ياتوزن ناشى از مواد إنان

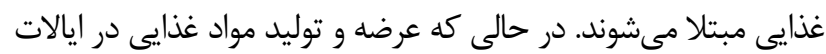
متحده يكى از امنترين نقاط در جهان است، مركز كنترل و ييشخيرى بيمارى اين كشور تخمين زده است كه بيمارىهاى ناشى از مواد غذايى

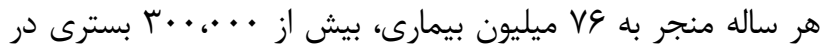

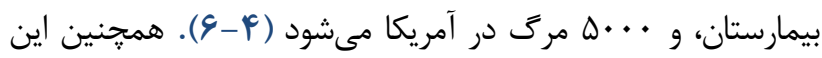

اصطلاح بيمارىهاى ناشى از غذا (foodborne diseases) كه بيشتر تحت عنوان مسموميت غذايى رايج است، براى مشخص كردن

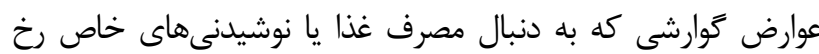

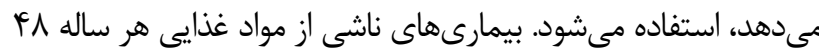

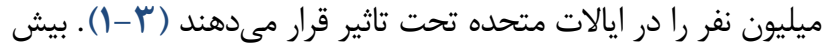

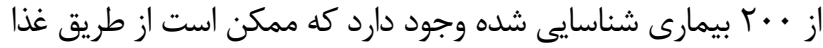

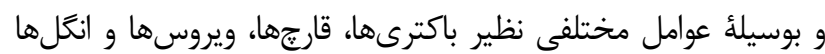


الاكتواستريتوسين) را ترشح مى كنند كه داراى طيف ضد ميكروبى

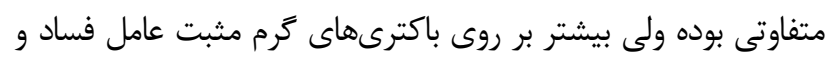

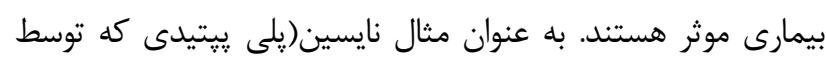

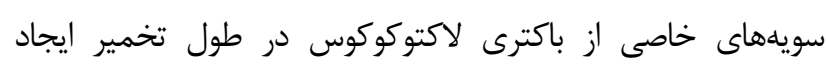

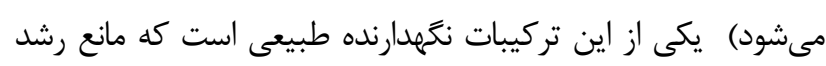

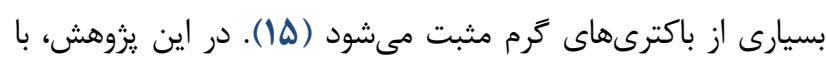

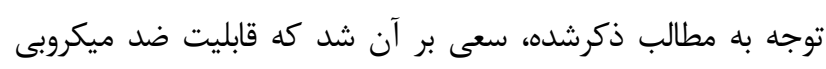

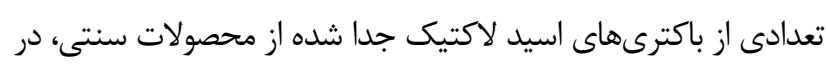
مقابل برخى از ياتوزنهاى شاخص مواد غذايى مورد ارزيابى قرار گيرد.

$$
\text { مواد و روشهاى سويل باكتريايى }
$$

در اين تحقيق از باكترىهاى جداسازى شده از ماست و شير

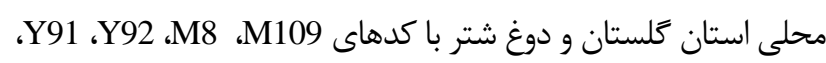
از مجموعلى CA از مجموعه ميكروبى كروه علوم و صنايع غذايى دانشكاه كركان تهيه

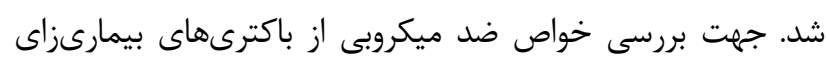

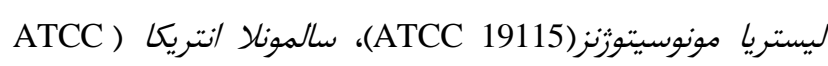

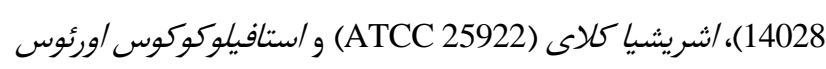

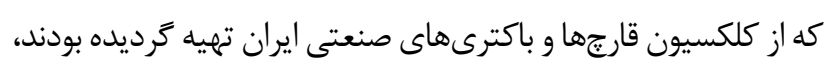
استفاده شد.

\section{فعالسازى جدايهها و بررسى اوليه جهت شناسايى فنوتيبى}

براى اين هدف، ابتدا احياسازى جدايهها در محيط كشت MRS

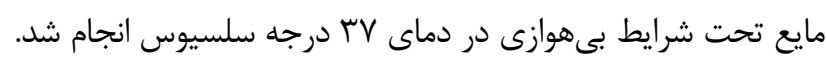

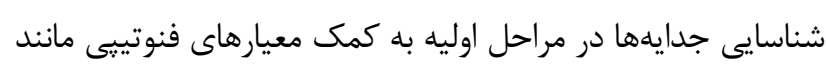

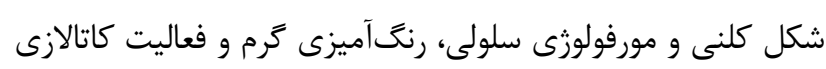
انجام شد. محيطهاى كشت MRS agar و و

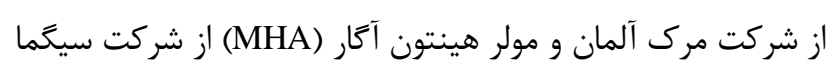
آمريكا تهيه شدند.

\section{شناسايى جدايهها به روش مولكولى}

استخراج DNA توسط كيت تجارى استخراج DNA (تكايو زيست، كره جنوبى) و بر اساس دستورالعمل كيت مورد استفاده انجام شد.

\section{واكنش زنجيرهاى يليمراز (PCR)}

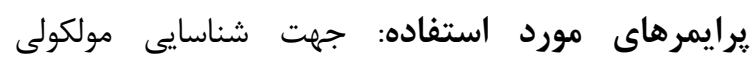

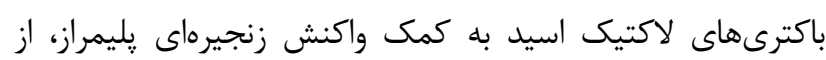

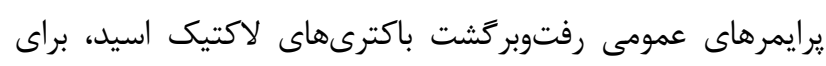
تكثير نواحى متغير 19S rDNA استفاده شد. توالى برايمرها عبارتاند

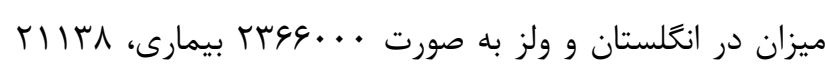

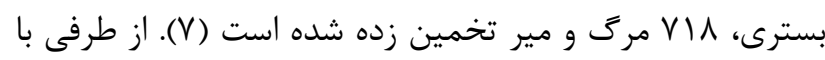

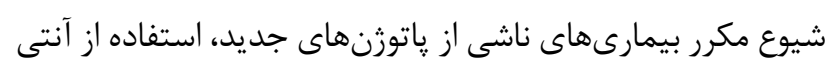

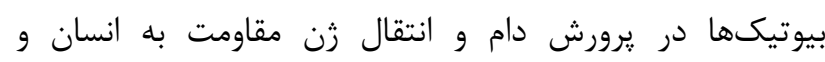

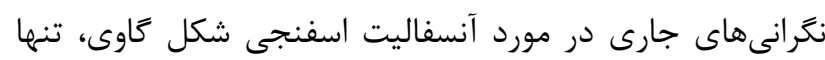

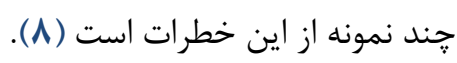
بنابراين على رغم بيشرفتهاى گسترداى كه در زمينه بهداشت

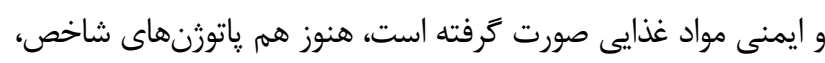

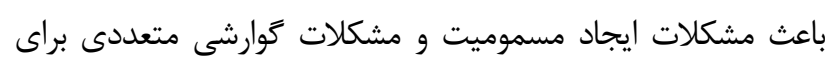

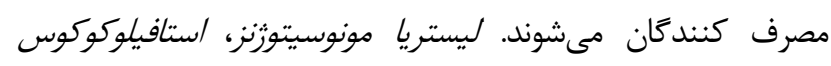

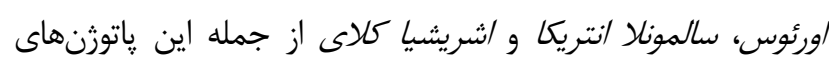

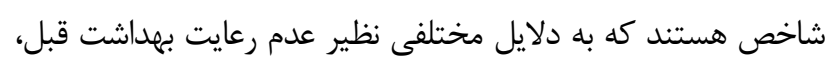

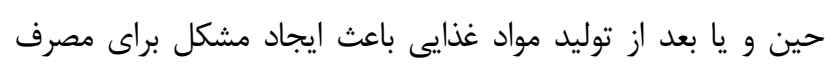
كنندكان مىشوند.

در طول دهه كذشته، علاقه زيادى به بهبود كيفيت و افزايش

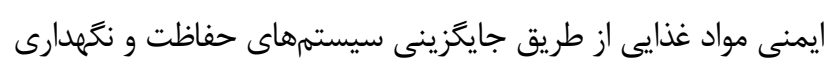

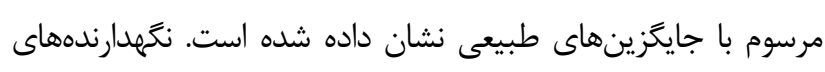

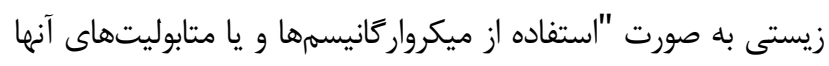

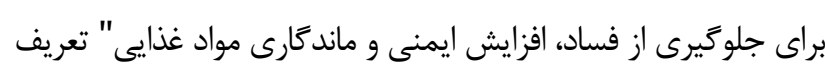

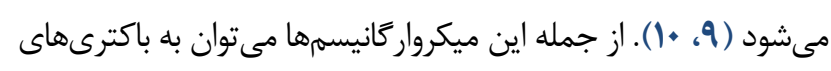

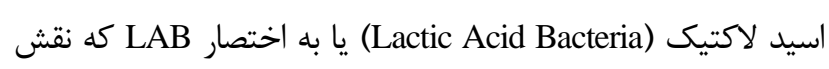

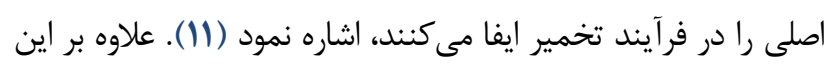

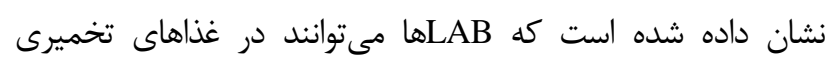

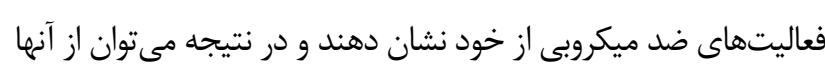

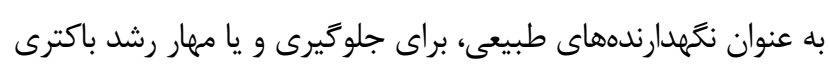

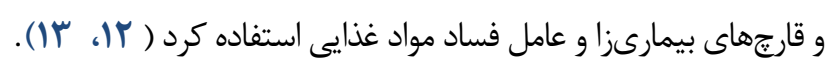
باكترىهاى لاكتيك اسيد به لحاظ توليد متابوليتهاى مختلف

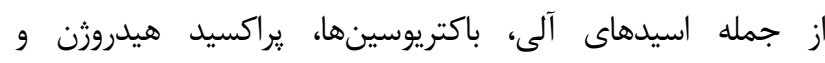

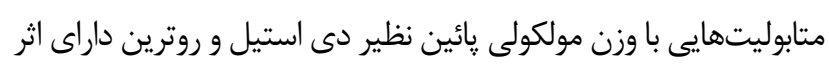

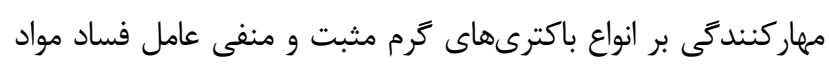

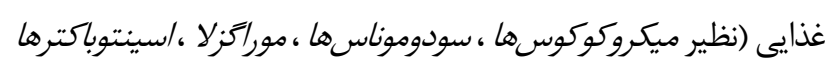

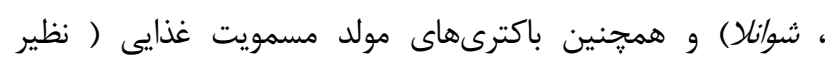

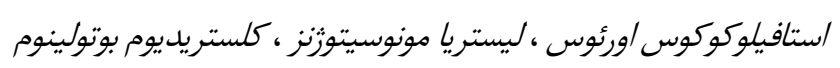

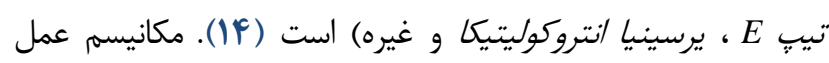

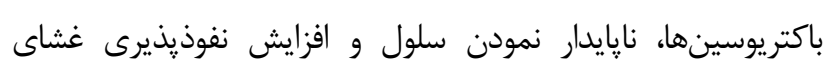

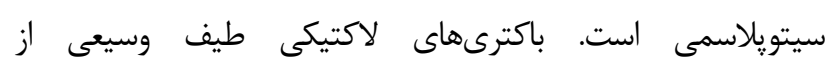

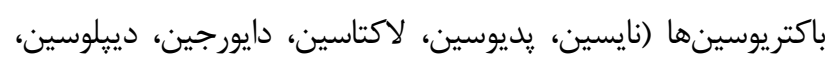




$$
\text { 1- } 100
$$

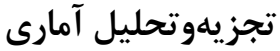

نتايج حاصل از اين يزوهش نيز با استفاده از آناليز واريانس

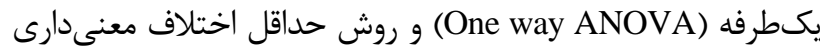
در سطح معنىدارى ه • (LSD) (SPSS Inc., Chicago, Ill., USA) 19 تجزيه و تحليل SPSS شد و براى ترسيم نمودارها از نرمافزار ميايكروسافت اكسل نسخه

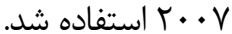

\section{نتايج}

\section{شناسايى مولكولى سويههاى فعال شده}

ارزيابى اوليه تكثير DNA تك يركنههاى حاصل از كشت خطى سوسيانسيون ميكروبى جدايههاى بهدست آمده با زل الكتروفورز محصولات توليدى، تائيد ترديد (شكل ()).

Pمانطور كه در شكل 1 مشاهده مىشود محصولات PCR

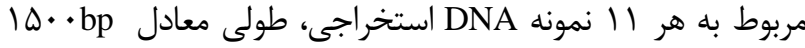
داشتند. توالى قطعات زن 19S rDNA جدايهها با توالىهاى ذخيره شده در קيايگاه اطلاعاتى NCBI، Blast ترديد (جدول ()). نتايج توالىيابى محصولات PCR داراى يرايمر اختصاصى از DNA اين تكى دأس

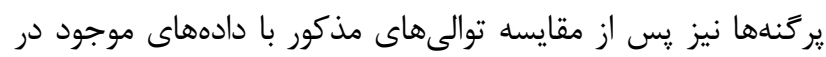

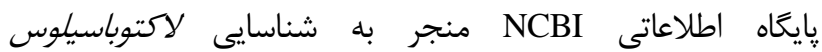

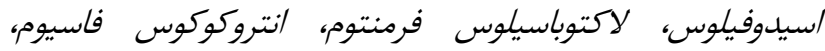
لاكتوباسيلوس برويس و لاكتوباسيلوس رامنوسوس شد. با توجه به نتايج بالا و تفاوتهاى آشكارى كه ميان شناسايى مولكولى و بيوشيميايى ديده مىشود مىتوان بلدقت و صحت شناسايى مولكولى

سويههاى ميكروبى با استفاده از ناحيه رنى 16S rDNA يى برد.

\section{خاصيت ضد باكتريايى جدايهها}

از بين جدايههاى شناسايى شده، |ل جدايه از جنس و كونههاى مختلف انتخاب شدند و سيس خاصيت ضد ميكروبى آنها در برابر باكترىهاى بيمارىزا به روش ميكرودايلوشن (شكل r تا شكل ه ه )

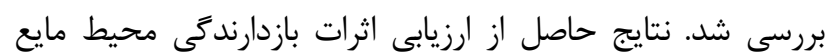
مصرف شده بدون سلول كشت جدايههاى لاكتيكى بر رشد ليستريا مونوسيتوزنز (شكلr) نشان داد كه درصد بازدارندىى محيط مايع

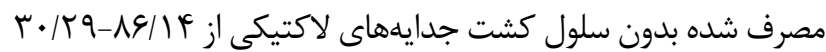
درصد متغير بود. در بين جدايهها /نتروكوكوس فاسيومC8 جدا شده

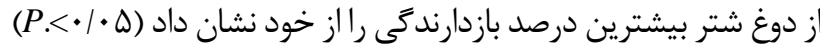

27F: 5’ - 1492R: 5'-GGTTACCTTGTTACGACTT-3º DNA AGAGTTTGATCCTGGCTCAG-3

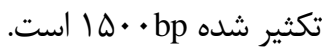

واكنش زنجيرهاى يليمراز: واكنش واكنش زنجيرهاى

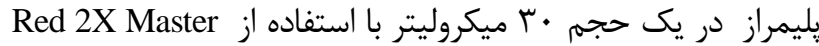
Mix

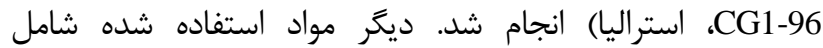
يروتئينازK (بيشكام، كره جنوبى)، Ladder (تكايو زيست، كره جنوبى) و DNA Safe Stain از شركت بيشگام كره جنوبى تهيه گرديد. مقادير به كار برده شده براى مستر، يرايمر رفت و برگشت، DNA الكو و آب

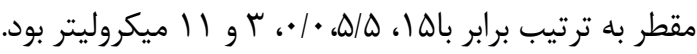
تعيين توالى و مقايسه توالىها: جهت تعيين توالى، محصولات واكنش واكنش زنجيرهاى يليمراز به شركت ماكروزن در لرين كره جنوبى ارسال شد. از يرايمر رفت نيز جهت تعيين توالى استفاده شد. با كمك برنامه Blast توالىهاى حاصل با توالىهاى موجود در در بانك جهانى رن (NCBI) مقايسه شدند. جدايههايى كه توالى آنها با موارد موجود در بانك اطلاعاتى، درصد مشابهت بالاترى را نشان دادند، بلمعنوان همان كونه شناسايى شدند.

\section{بررسى قابليت ضد باكتريايى جدايهها}

بdمنظور ارزيابى خاصيت ضد ميكروبى محيط مايع مصرف شده

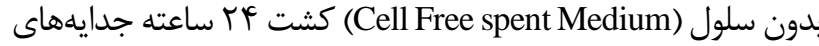
لاكتيكى در برابر باكترىهاى بيمارىزا شامل ليستريا مونوسيتوزنز،

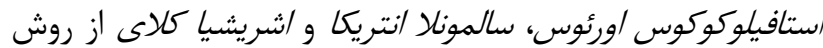

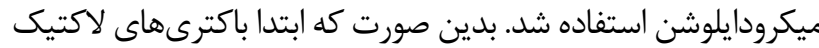

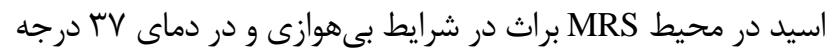

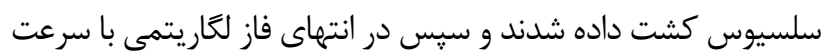

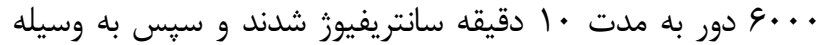

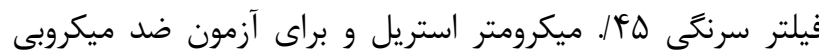
استفاده شدند. در ادامه براى تعيين اثر ضد ميكروبى، ذها إميكروليتر از محيط مايع مصرف شده بدون سلول كشت هر جدايه لاكتيكى كه

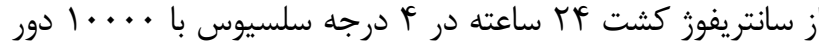

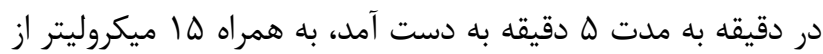
باكترى بيمارىزاى مورد نظر (حاوى CFU ه • () به هر خاهك اضافه

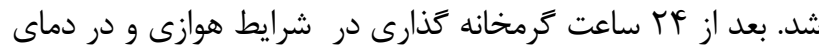

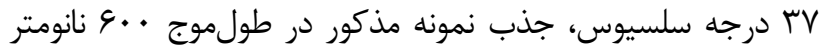

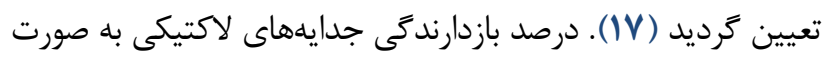

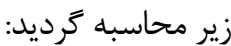


كرم منفى شامل /شريشيا كلاى (شكل f) و سالمونلا انتريكا (شكل

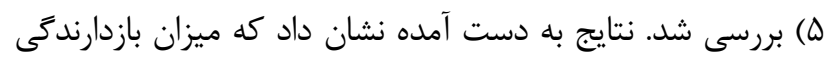

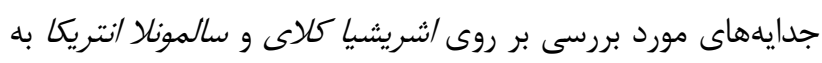

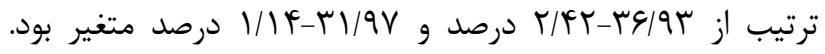

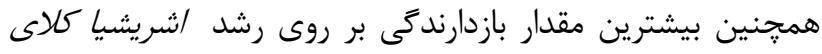

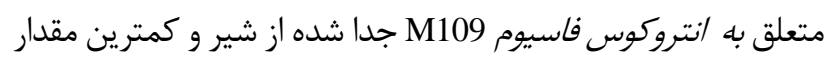
بازدارندگى متعلق به لاكتوباسيلوس برويس Y92 جدا شده از ماست

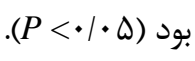

همجنين بين درصد بازدارندكى لاكتوباسيلوس رامنوسوس Y89،

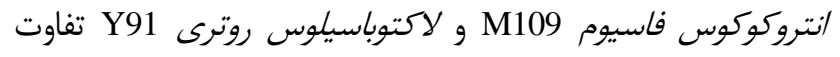
معنى دارى مشاهده نشد. همجنين لاكتوباسيلوس برويس

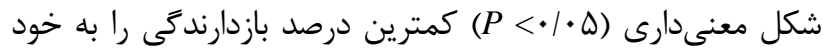

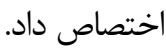

در بخش ديخرى از اين : يزوهش، اثرات بازدارندگى محيط مايع مصرف شده بدون سلول كشت جدايههاى لاكتيكى بر رشد دو باكترى

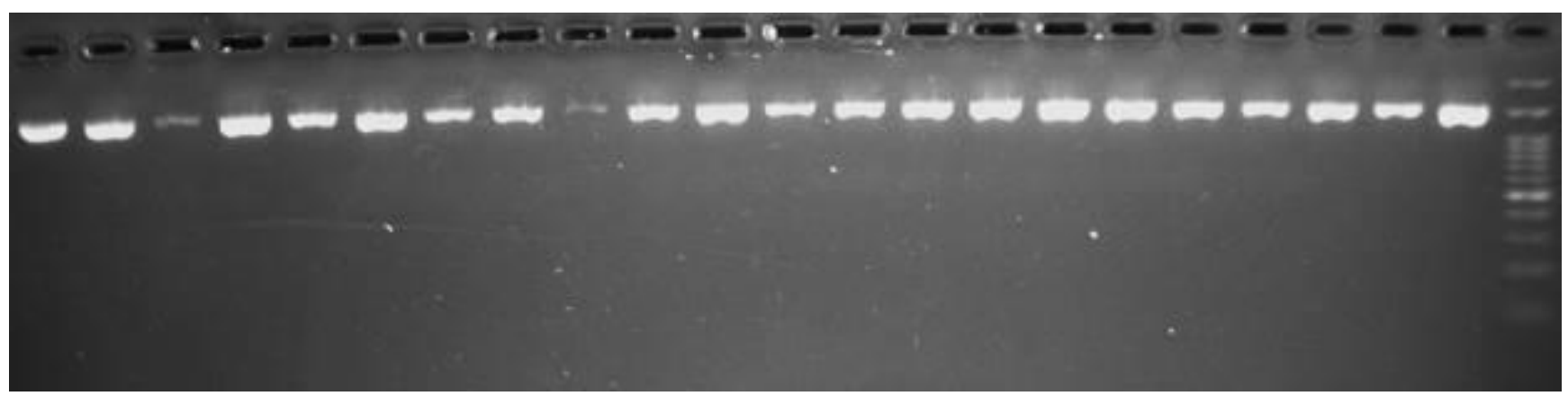

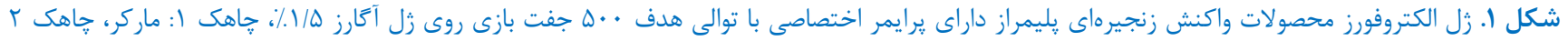

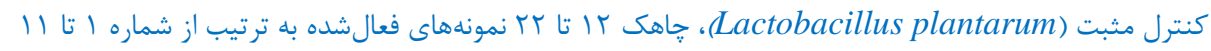

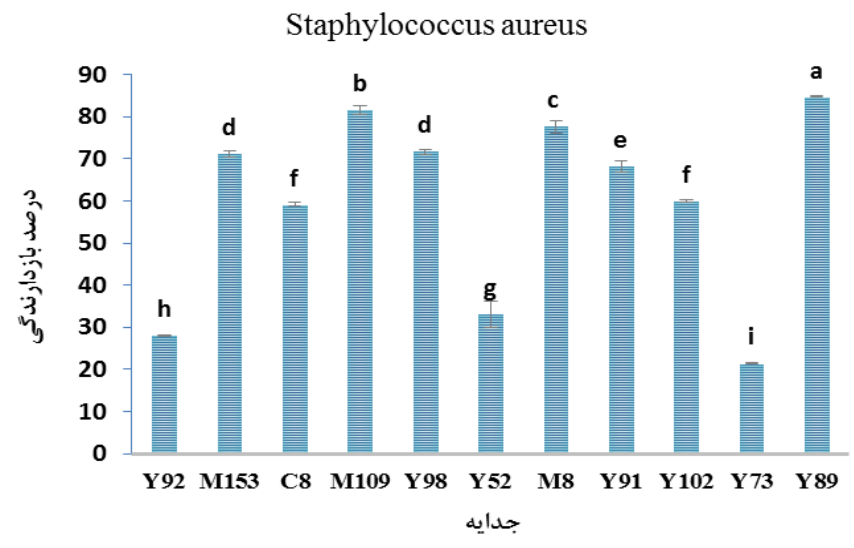

شكل r. اثرات بازدارندگى محيط مايع مصرف شده بدون سلول كشت جدايdهاى لاكتيكى بر رشد استافيلوكوس اورئوس

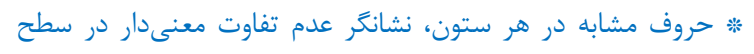

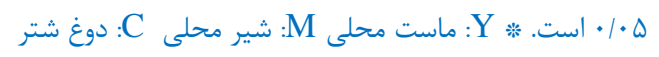

Listeria monocytogenes

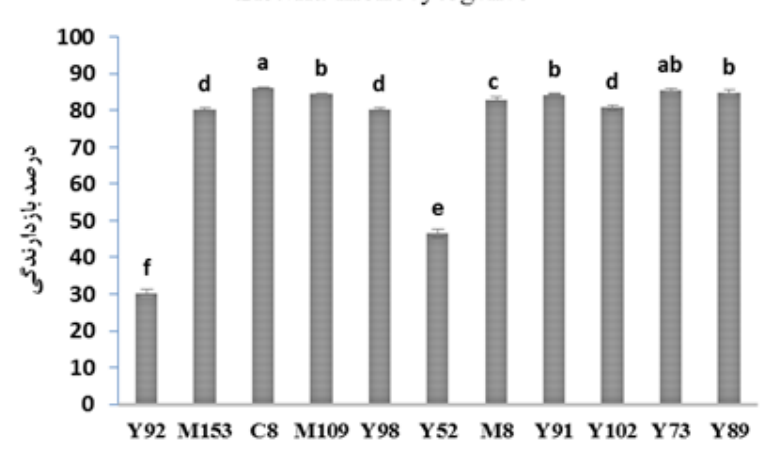

جدايه

شكل r. اثرات بازدارندگى محيط مايع مصرف شده بدون سلول كشت جدايههاى لاكتيكى بر رشد ليستريا مونوسيتوزنز

* حروف مشابه در هر ستون، نشانكر عدم تفاوت معنى دار در سطح ه • | .

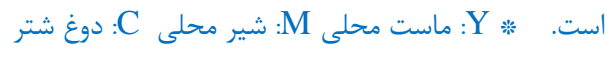



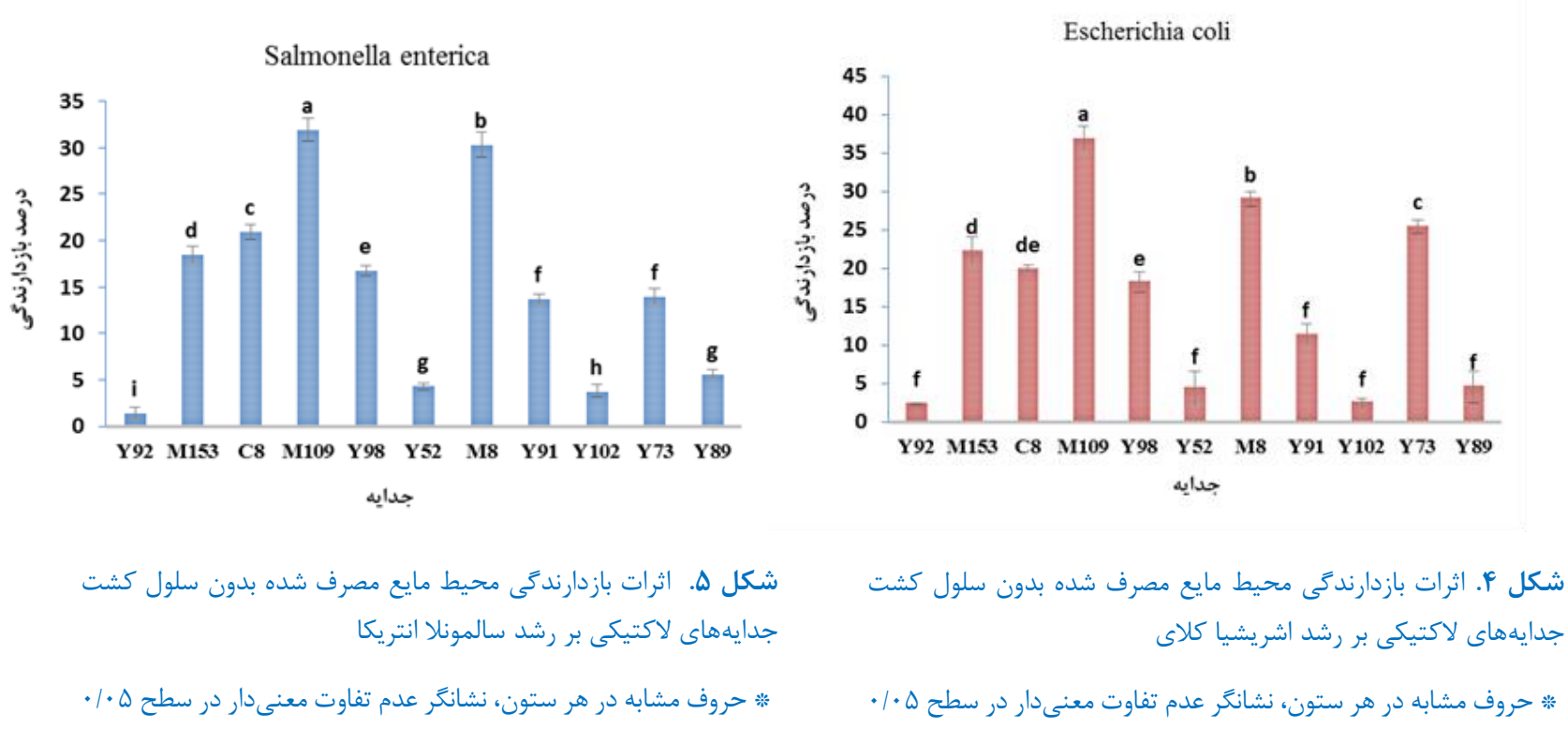

در بين همه جدايهها به شكل معنىدارى بيشتر از ميزان

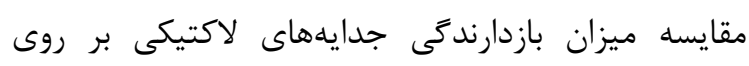

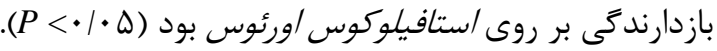

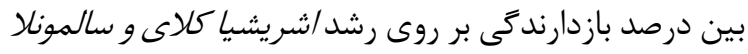

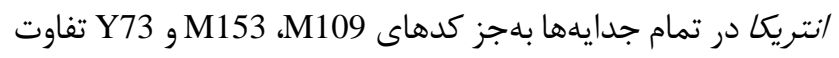

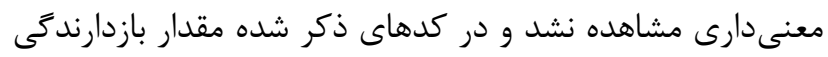

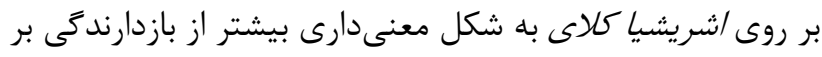

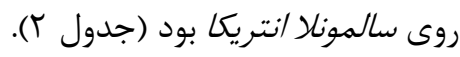

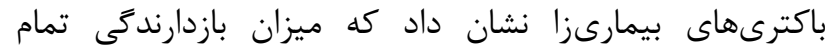

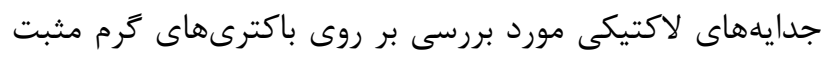

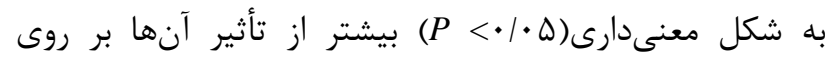

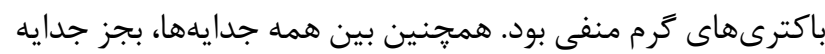

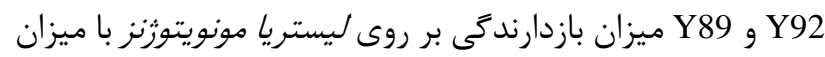

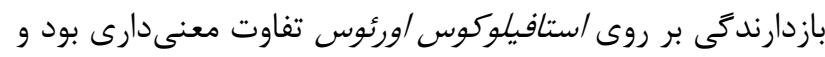

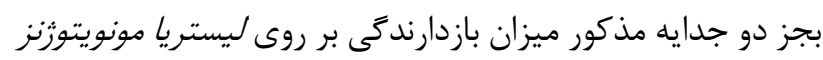

جدول r. مقايسه ميزان بازدارندَى جدايههاى لاكتيكى بر روى باكترىهاى بيمارىزا

\begin{tabular}{|c|c|c|c|c|c|}
\hline $\begin{array}{c}\text { Salmonella } \\
\text { enterica }\end{array}$ & Escherichia coli & $\begin{array}{c}\text { Staphylococcus } \\
\text { aureus }\end{array}$ & $\begin{array}{c}\text { Listeria } \\
\text { monocytogenes }\end{array}$ & كد جدايه & شماره \\
\hline $1 / \cdot \pm r / q \varphi^{b}$ & $r / \cdot \pm F \psi / l \Delta^{b}$ & $r N / \cdot \pm I r / I V^{a}$ & $r \cdot / \cdot \pm r q / 9 r^{a}$ & Y92 & 1 \\
\hline $\mid N / \cdot \pm \uparrow \varepsilon / q^{d}$ & $r r / \Lambda \pm r q / V q^{c}$ & $V \backslash / \cdot \pm I V / q^{b}$ & $\Lambda \cdot / \cdot \pm \kappa \varepsilon /\left\{r^{a}\right.$ & M153 & 2 \\
\hline$r \cdot / \cdot \pm q r / V q^{c}$ & $19 / \cdot \pm 99 / \Delta \mu^{c}$ & $\Delta q / \cdot \pm 11 / q \mu b$ & $\Lambda \varepsilon / \cdot \pm \mid f / \cdot \wedge \Delta^{a}$ & $\mathrm{C} \wedge$ & 3 \\
\hline$r y / 1 \pm 9 V / r l^{d}$ & 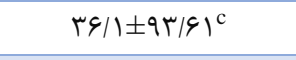 & $\Lambda 1 / 1 \pm \Delta q / \cdot \varphi^{b}$ & $\Lambda F / \cdot \pm r \wedge / \cdot \wedge^{\mathrm{a}}$ & M109 & 4 \\
\hline $\mid \varepsilon / \cdot \pm V F / \Delta \Delta^{c}$ & $|N /| \pm r \mid / r \varphi^{c}$ & $V \backslash / \cdot \pm V \backslash / q^{b}$ & $\Lambda \cdot / \cdot \pm f \& / f r^{a}$ & Y98 & 5 \\
\hline$F / \cdot \pm r \mid / r V^{c}$ & $r / r \pm F / / r q^{c}$ & $r r / r \pm 1 Q / I r^{b}$ & $\varphi \varepsilon / 1 \pm \Delta \varepsilon / r \Delta^{\mathrm{a}}$ & Y52 & 6 \\
\hline$r \cdot / 1 \pm r F / r r^{c}$ & $r q / \cdot \pm \cdot N / q \Delta^{c}$ & $V V / I \pm \varepsilon V / F \wedge^{b}$ & $\Lambda r / \cdot \pm \cdot q / \Delta^{a}$ & M8 & 7 \\
\hline $\mid r / \cdot \pm g V / \Delta Y^{c}$ & $11 / 1 \pm F F / F^{c}$ & $G \Lambda / I \pm I F / \mu^{b}$ & $\Lambda \kappa / \cdot \pm \kappa / / \gamma^{a}$ & Y91 & 8 \\
\hline$r / \cdot \pm \bigvee \wedge / \varepsilon \Lambda^{c}$ & $r / \cdot \pm \Delta / \varepsilon V^{c}$ & $\Delta q / \cdot \pm q \Lambda / r^{b}$ & $\Lambda \cdot / \cdot \pm \Lambda \vee / 9 V^{a}$ & Y102 & 9 \\
\hline $\mid r / \cdot \pm 9 \Delta / \wedge r^{d}$ & $r \Delta / \cdot \pm r r / \Lambda \Lambda^{b}$ & $r I / \cdot \pm r N / I r^{c}$ & $\wedge \Delta / \cdot \pm F q / \Delta q^{a}$ & Y73 & 10 \\
\hline$\Delta / \cdot \pm \varepsilon \Delta / \& \varepsilon^{b}$ & $\boldsymbol{q} / r \pm \varepsilon r / \cdot V^{b}$ & $\Lambda F / \cdot \pm V \backslash / I V^{a}$ & $\Lambda F / \cdot \pm q / q v^{a}$ & Y89 & 11 \\
\hline
\end{tabular}

'حروف مشابه در هر رديف، نشانكر عدم تفاوت معنى دار در سطح ه • • است. 
نتايج اثرات بازدارندگى جدايههاى لاكتيكى بر رشد /شريشيا

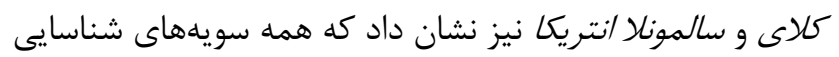

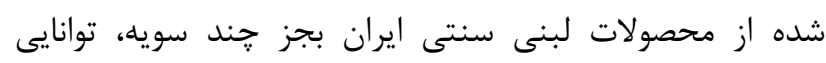

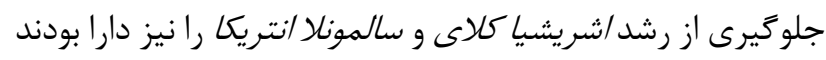

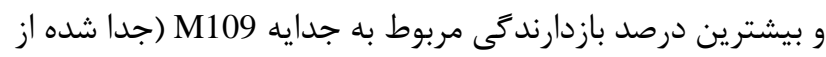

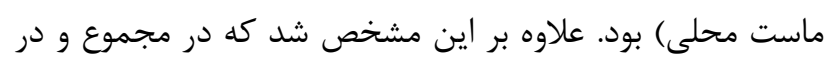

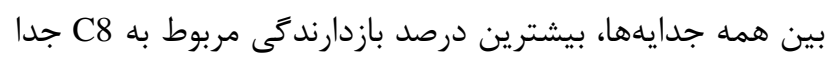

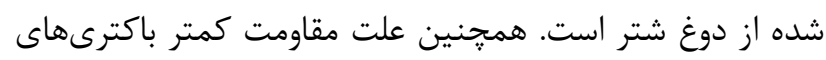

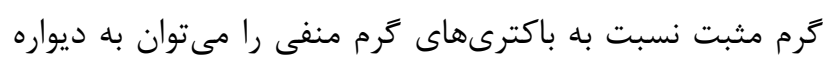

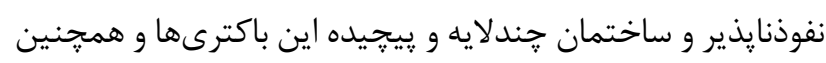

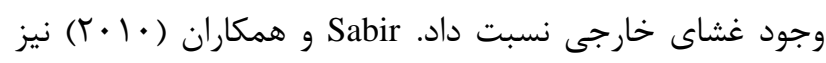

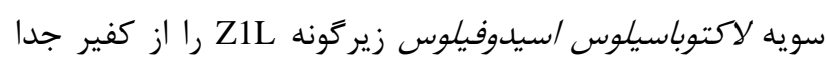

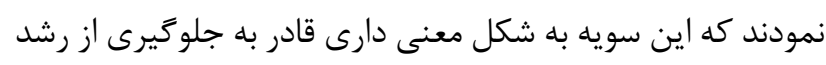

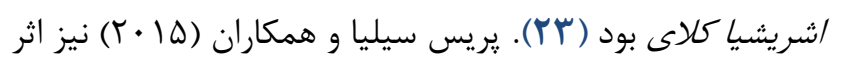

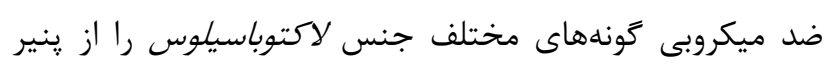

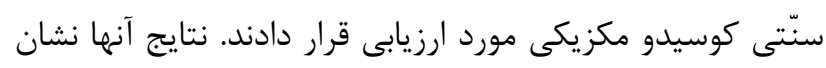

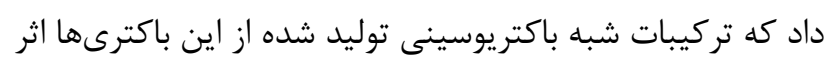

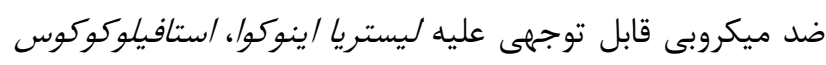

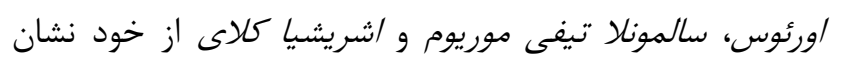

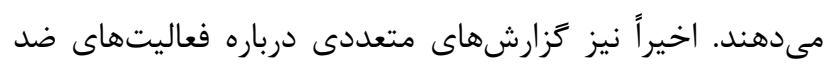

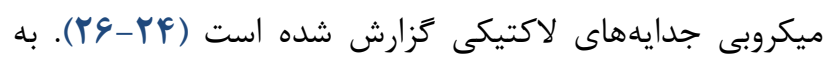

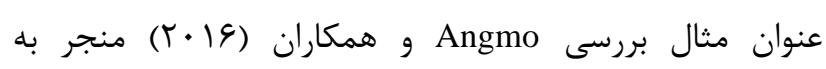

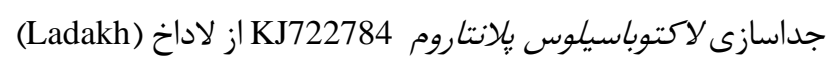

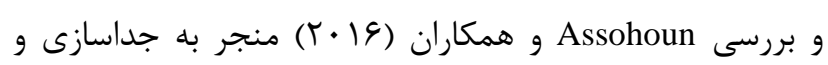

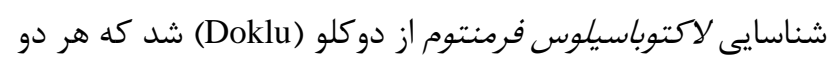

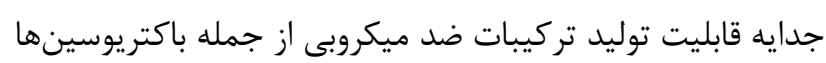

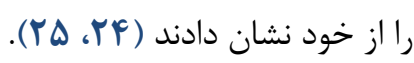

باكتريوسينها با اتصال به ليييد II از سنتز ديواره سلولى

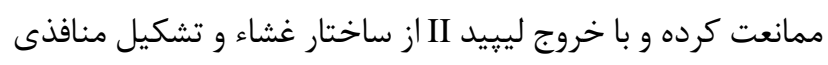

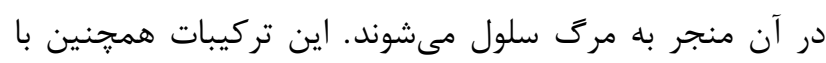

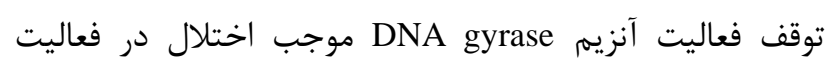

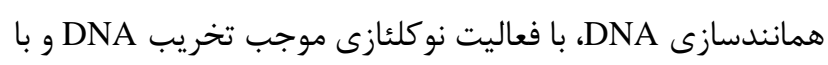

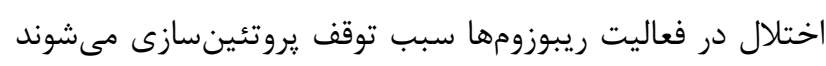

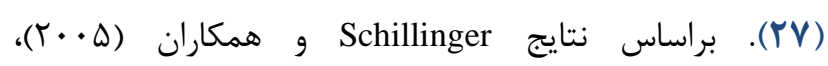
لاكتوباسيلوس /سيدوفيلوس از قابليت تجمعى قابل توجهى عليه

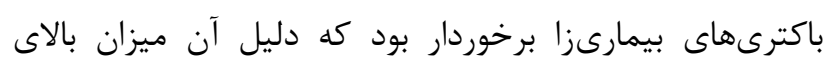

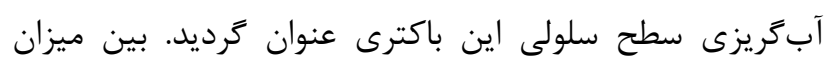

با توجه به نتايج اين يزوهش، جنسهاى لاكتوباسيلوس و و

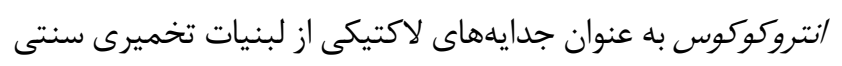

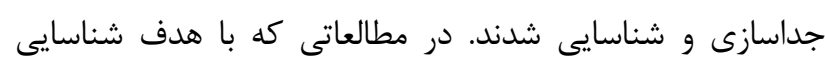

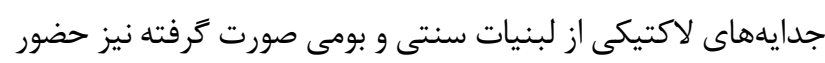

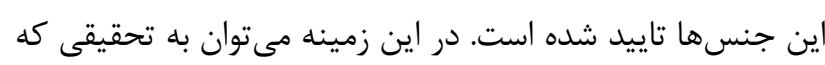

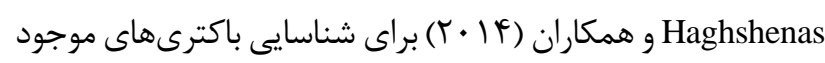
در لبنيات سنتى استفاده كردند اشاره كرد كه منجر به شنارئ (بناسايى

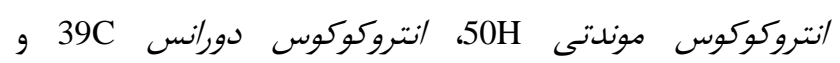

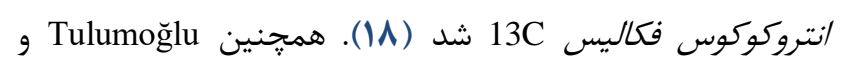

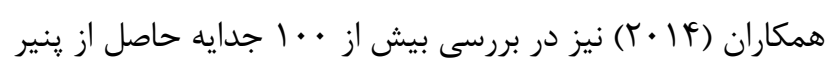

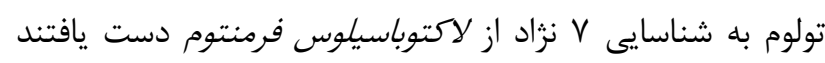

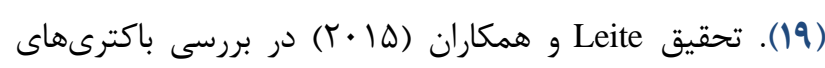

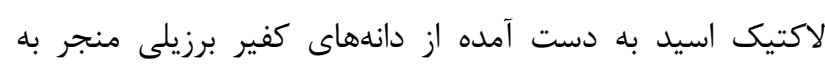

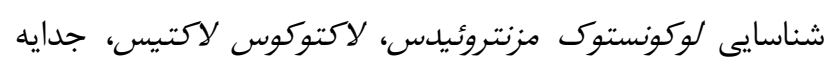

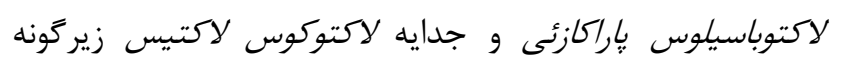

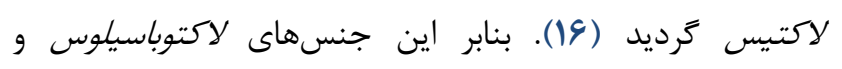

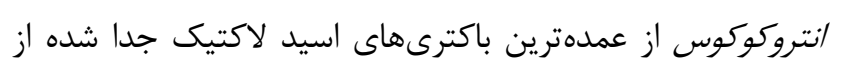
لبنيات سنتى و بومى هستند. نتايج حاصل از ارزيابى اثر بازدارندگى جدايههاى لاكتيكى بر

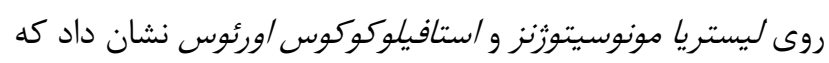

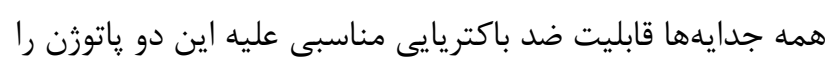

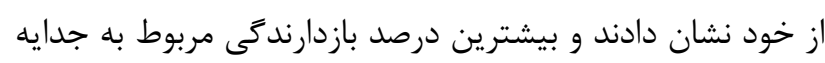

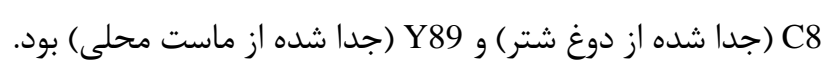

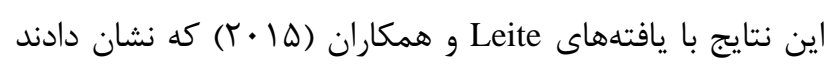
جدايههاى لاكتيكى لاكتوكوس لاكتيس، لوكونستوك مزنتروئيدس

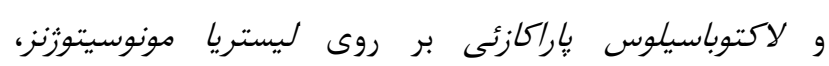

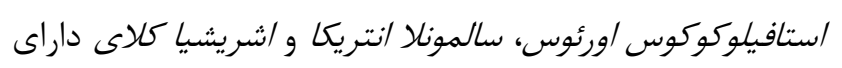

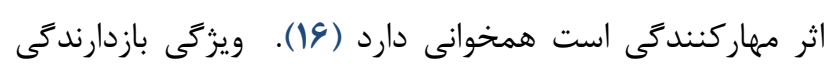

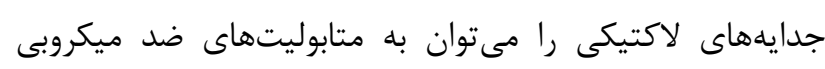

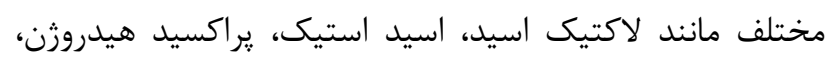

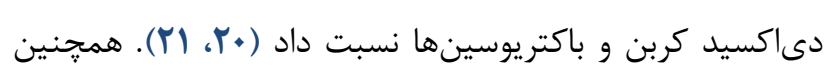
Casaburi

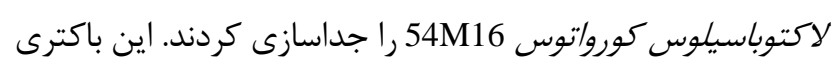

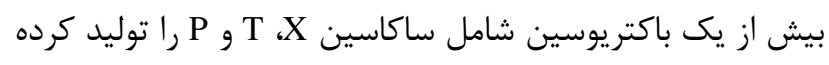

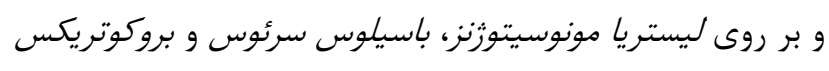

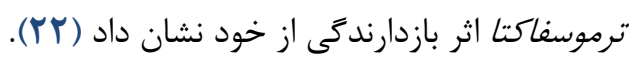


رامنوس Y89 جدا شده از ماست و /نتروكوكوس فاسيوم جدا شده از دوغ شتر به ترتيب بيشترين درصد بازدارندىى را بر ليستريا مونوسيتوزنز و /ستافيلوكوكوس اورئوس از خود نشان دادند.

مقايسه ميزان بازدارندگى جدايههاى لاكتيكى بر روى

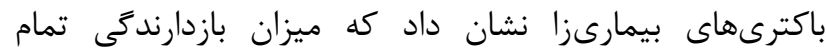

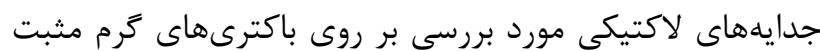

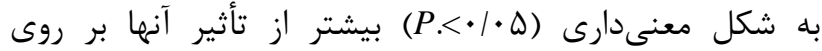
باكترىهاى كرم منفى بود. بر اساس نتايج اين تحقيق، همه سويههاى جدا شده و شناسايىشده از اين محصولات لبنى، قابليت جلوكيرى از رشد باكترىهاى بيمارىزاى گرم مثبت ليستريا

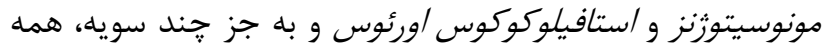

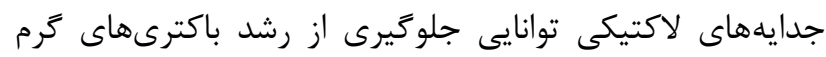

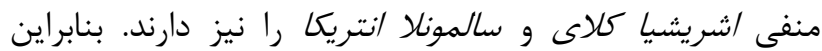
ي ريشنهاد مىشود كه از جدايههاى لاكتيكى بهدست آمده از ماست،

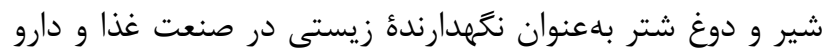

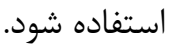

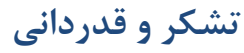

بدين وسيله نويسندكان اين مقاله بر خود لازم مى داند كه از معاون يزوهشى مركز تحقيقات كشاورزى خوزستان و نيز مديريت شركت يرهام جنوب كه در اين مطالعه با ما همكارى نمودند كمال

$$
\text { تشكر و قدرانى را به عمل آورد. }
$$

$$
\text { تعارض منافع }
$$

\section{Referance}

1. Scallan E, Griffin PM, Angulo FJ, Tauxe RV, Hoekstra RM. Foodborne illness acquired in the United Statesunspecified agents. Emerging Infect. Dis. 2011; 17:16. [DOI:10.3201/eid1701.P21101] [PMID] [PMCID]

2. Dewey-Mattia D, Manikonda K, Hall AJ, Wise ME, Crowe SJ. Surveillance for foodborne disease outbreaks-United States, 2009-2015. MMWR Surveillance Summaries. 2018 Jul 27;67(10):1. [DOI:10.15585/mmwr.ss6710a1] [PMID] [PMCID]

3. Upadhayay UPPDD, Evum PCVVV. Food-home Pathogens of Animal Origin-Diagnosis, Prevention, Control and Their Zoonotic Significance: A Review. Pak J Biol Sci. 2013; 16: 1076-85. [DOI:10.3923/pjbs.2013.1076.1085] [PMID]
آبكريزى ديواره سلولى و قابليت تجمع باكترىهاى اسيد لاكتيك بر

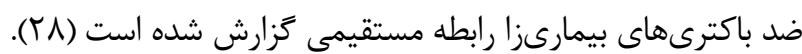
لاكتوباسيلوس /سيدوفيلوس و لاكتوباسيلوس كازرى جدا شده توسط

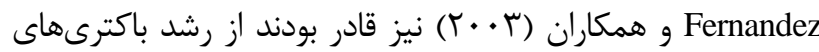

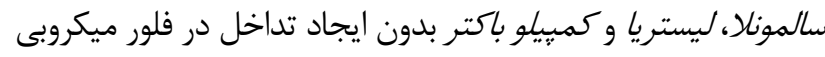

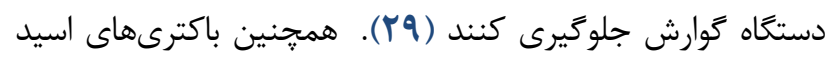
لاكتيك داراى توانايى كاهش ميزان كلسترول، ايمنسازى سيسته دفاعى و خاصيت ضد تومورى هستند (•ץ). توانايى توليد برخى از

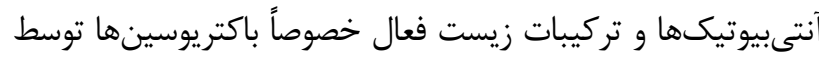
اين باكترىها جهت كنترل و درمان برخى از سرطانهاى دستكاه كوارش به اثبات رسيده است (•r).

با توجه به اهميت خصوصيات ويزه جدايههاى لاكتيكى از

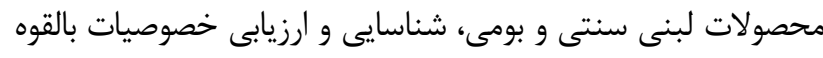

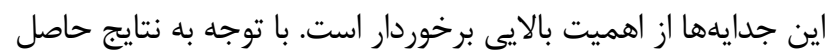

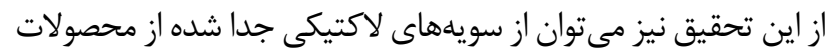

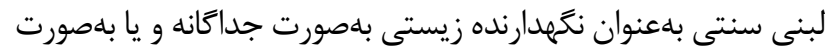

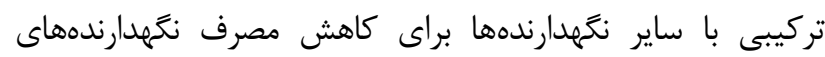
سنتزى و يا بهعنوان كشت آغازگ در در صنعت غذا استفاده نمود.

$$
\text { نتيجه }
$$

نتايج توالى يابى محصولات PCR، منجر به شناسايى جنسهاى لاكتوباسيلوس و/نتروكوكوس از لبنيات تخميرى سنتى شد. همجنين

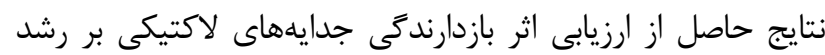

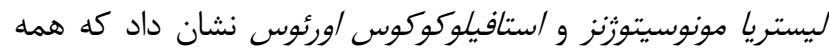

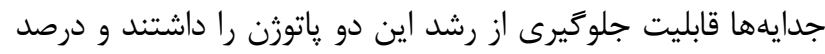

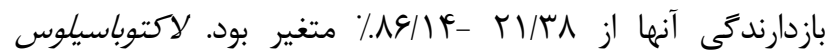

4. Control CfD, Prevention. Multistate outbreak of Salmonella serotype typhimurium infections associated with drinking unpasteurized milk--Illinois, Indiana, Ohio, and Tennessee, 2002-2003. MMWR Morbidity and mortality weekly report. 2003; 52: 613.

5. Control CfD, Prevention. Preliminary FoodNet data on the incidence of infection with pathogens transmitted commonly through food--selected sites, United States, 2003. MMWR Morbidity and mortality weekly report. 2004; 53: 338.

6. Oliver SP, Jayarao BM, Almeida RA. Foodborne pathogens, mastitis, milk quality, and dairy food safety. InNMC Annual Meeting Proceedings 2005 (Vol. 1). 
7. Rocourt J, Moy G, Vierk K, Schlundt J. The present state of foodborne disease in OECD countries. World Heath Organization: Geneva.

8. Medeiros LC, Hillers VN, Kendall PA, Mason A. Food safety education: what should we be teaching to consumers. J Nutr Educ. 2001; 33: 108-13. https://doi.org/10.1016/S1499-4046(06)60174-7 [DOI:10.1016/S1499-4046(06)60067-5]

9. Cortés-Zavaleta O, López-Malo A, HernándezMendoza A, García H. Antifungal activity of lactobacilli and its relationship with 3-phenyllactic acid production. Int J Food Microbiol. 2014; 173: 305. [DOI:10.1016/j.ijfoodmicro.2013.12.016] [PMID]

10. Muhialdin BJ, Hassan Z. Screening of lactic acid bacteria for antifungal activity against Aspergillus oryzae. Am J Appl Sci. 2011; 8: 447. [DOI:10.3844/ajassp.2011.447.451]

11. Pawlowska AM, Zannini E, Coffey A, Arendt EK. 5" Green Preservatives": Combating Fungi in the Food and Feed Industry by Applying Antifungal Lactic Acid Bacteria. Adv Food Nutr Res. 2012; 66: 217. [DOI:10.1016/B978-0-12-394597-6.00005-7] [PMID]

12. Li H, Zhang S, Lu J, Liu L, Uluko H, Pang X, et al. Antifungal activities and effect of Lactobacillus casei AST18 on the mycelia morphology and ultrastructure of Penicillium chrysogenum. Food Control. 2014; 43: 57-64. [DOI:10.1016/i.foodcont.2014.02.045]

13. Ahmadova A, Todorov SD, Hadji-Sfaxi I, Choiset $\mathrm{Y}$, Rabesona H, Messaoudi S, et al. Antimicrobial and antifungal activities of Lactobacillus curvatus strain isolated from homemade Azerbaijani cheese. Anaerobe. 2013; 20: 42-9. [DOI:10.1016/j.anaerobe.2013.01.003] [PMID]

14. Lauzon, H.L. 2002. Development of biological control for Listeria spp.. in the manufacture of cold -smoked fish. Project Report. Icelandic Fisheries Laboratories.

15. Naidu, S.A. 2000. Natural food antimicrobial system, (1st ed.) CRC press. Washington, USA [DOI:10.1201/9781420039368] [PMCID]

16. Leite AMO, Miguel MAL, Peixoto RS, Ruas-Madiedo P, Paschoalin VMF, Mayo B, Delgado S. Probiotic potential of selected lactic acid bacteria strains isolated from Brazilian kefir grains. J Dairy Sci. 2015; 6: 36223632. [DOI:10.3168/jds.2014-9265] [PMID]

17. Méndez-Vilas A, editor. Microbial pathogens and strategies for combating them: science, technology and education. Formatex Research Center; 2013.

18. Haghshenas B, Nami Y, Abdullah N, Radiah D, Rosli R. Yari Khosroushahi A. Anti-proliferative effects of Enterococcus strains isolated from fermented dairy products on different cancer cell lines. J Funct Foods. 2014; 11: 363-374. [DOI:10.1016/j.jff.2014.10.002]
19. Tulumoğlu S, Kaya HI, Simsek o. Probiotic characteristics of Lactobacillus fermentum strains isolated from tulum cheese. Anaerobe. 2014; 30: 120 125. [DOI:10.1016/j.anaerobe.2014.09.015] [PMID]

20. Patil MM, Pal A, Anand T, Ramana K.V .Isolation and characterization of Lactic acid bacteria from curd and cucumber. Indian J Biotechnol. 2010; 9, 166-172.

21. Leroy F, De Vuyst L. Lactic acid bacteria as functional starter cultures for the food fermentation industry. Trends Food Sci Tech. 2004; 15: 67-78. [DOI:10.1016/j.tifs.2003.09.004]

22. Casaburi A, Martino VD, Ferranti P, Picariello L, Villani F. Technological properties and bacteriocins production by Lactobacillus curvatus 54M16 and its use as starter culture for fermented sausage manufacture. Food Control. 2016; 59: 31-45. [DOI:10.1016/i.foodcont.2015.05.016]

23. Sabir F, Beyatli Y, Cumhur C. Assessment of potential probiotic properties of lactobacillus spp.., lactococcus spp.., and pediococcus spp. strains isolated from kefir. J Food Sci. 2010; 759: 568-573. [DOI:10.1111/j.17503841.2010.01855.x] [PMID]

24. Angmo K, Kumari A, Savitri A, Bhalla TC. Probiotic characterization of lactic acid bacteria isolated from fermented foods and beverage of ladakh. Food Sci Tech. 2016; 66: 428-432. [DOI:10.1016/j.1wt.2015.10.057]

25. Assohoun-Djeni, NMC, Djeni NT, Messaoudi S, Lhomme E, Koussemon-Camara M, Ouassa T, et al. Biodiversity, dynamics and antimicrobial activity of lactic acid bacteria involved in the fermentation of maize flour for doklu production in Côte d'Ivoire. Food Control. 2016; 62: 397-404. [DOI:10.1016/j.foodcont.2015.09.037]

26. Caballero B, Finglas P, Toldrá F. Encyclopedia of food and health. Academic Press; 2015 Aug 26.

27. Schaechter M. Encyclopedia of microbiology. 5th ed. Academic Press; 2011 Jan 14; 85-90.

28. Schillinger U, Guigas C, Holzapfel, WH. In vitro adherence and other properties of lactobacilli used in probiotic yoghurt-like products. Int Dairy J. 2005; 15: 1289-1297. [DOI:10.1016/j.idairyj.2004.12.008]

29. Fernandez M, Boris S, Barbes C. Probiotic properties of human lactobacilli strains to be used in the gastrointestinal tract. J Appl Microbiol. 2003; 94: 449455. [DOI:10.1046/j.1365-2672.2003.01850.x] [PMID]

30. Poutanen K, Flander L, Katina K.. Sourdough and cereal fermentation in a nutritional perspective. Food Microbiol. 2009; 26: 693-699. [DOI:10.1016/j.fm.2009.07.011] [PMID] 